\title{
EFFECT OF SPACING ON INITIAL GROWTH AND PRODUCTION OF EUCALYPTUS IN A SYSTEMIC "FAN-SHAPED” DESIGN
}

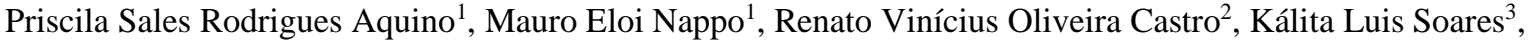 \\ Mirella Basileu de Oliveira $\mathrm{Lima}^{4}$ \\ ${ }^{1}$ University of Brasília, Department of Forest Engineering, Brasília, DF, Brazil - priscila.ueg@ gmail.com*, \\ mauronappo@yahoo.com.br \\ ${ }^{2}$ Federal University of São João Del Rei, Department of Forest Engineering, São João Del Rei, Minas Gerais, Brazil - \\ castrorvo@ymail.com \\ ${ }^{3}$ University of São Paulo, Department of Forest Sciences, Piracicaba, São Paulo, Brazil - soares-kalita@ hotmail.com \\ ${ }^{4}$ Federal University of Paraná, Graduate Program in Forest Engineering, Curitiba, Paraná, Brazil - mirellabasileu@gmail.com
}

Received for publication: 12/06/2019 - Accepted for publication: 08/09/2019

\begin{abstract}
Resumo
Crescimento e produção inicial de eucalipto em função do espaçamento em delineamento sistemático tipo "leque". Considerando a importância da otimização da produção florestal o espaçamento de plantio é umas das práticas silviculturais de maior relevância, pois apresenta implicações ecológicas, silviculturais e econômicas no produto final. Portanto, o objetivo do trabalho foi avaliar a influência do espaçamento nas variáveis de crescimento e produção inicial de um híbrido clonal de Eucalyptus urophylla S. T. Blake x Eucalyptus grandis W. Hill ex Maiden implantado sob delineamento sistemático tipo "leque". As densidades plantio variaram de $0,50 \mathrm{~m}^{2}$ a 41,25 $\mathrm{m}^{2}$ de área por planta. As variáveis altura total, diâmetro e volume foram avaliadas aos 16, 24 e 36 meses. Utilizou-se análise estatística descritiva, correlação linear de Pearson e análise de agrupamento de média para avaliação do efeito dos espaçamentos nas variáveis estudadas. Verificou-se que o crescimento em altura, diâmetro e volume sofreram influência significativa dos diferentes espaçamentos.

Palavras-chave: círculos de Nelder, densidade de plantio, Eucalyptus sp.
\end{abstract}

\section{Abstract}

Considering the importance of optimizing forest production, plant spacing is one of the most relevant silvicultural practices, as it holds ecological, silvicultural, and economic implications to the final product. Therefore, this study set out to assess the influence of spacing on the initial growth and production variables of hybrid clones of Eucalyptus urophylla S. T. Blake x Eucalyptus grandis W. Hill ex Maiden planted in a Nelder (fan-shaped) design. Plant densities ranged from $0.50 \mathrm{~m}^{2}$ to $41.25 \mathrm{~m}^{2}$ in area-per-plant. Variables such as total height, diameter, and volume were observed at 16, 24, and 36 months. A descriptive statistical analysis, Pearson's correlation coefficient, and cluster analysis of averages were used to evaluate the effect of spacing on the variables in question. Different spacings were found to exert significant influences on growth in height, diameter, and volume.

Keywords: Nelder wheels, plant density, Eucalyptus sp., silviculture

\section{INTRODUCTION}

Silviculture is the predominant basis for the forestry sector; therefore, all findings obtained through this science will be reflected in socioeconomic and environmental implications. Some of the most important silvicultural practices include choosing the species/provenance, use of hybridization and cloning, soil preparation, conservation, fertilization, and correction; silvicultural cutting practices for cleaning, clearance, health, pruning, and thinning; regeneration methods such as coppice sprouting; and plant spacing in high forest regime, in addition to other methods that define management (XAVIER; SILVA, 2010; SOUZA et al., 2010; OLIVEIRA et al., 2012; CARON et al., 2015).

Considering the relevance of optimizing forest production through management, proper spacing is fundamental due to its ecological and silvicultural implications to the final product. Spacing must not only be based on the end use of forest production but on several other ecological, physiological, silvicultural, and economic factors (BALLONI; SIMÕES, 1980). However, determining the best spacing is no simple matter. Various studies by Balloni e Simões (1980), Nascimento et al. (2012), Benin et al. (2014) e Leles et al. (2014) have been conducted, and others are currently underway in order to improve silvicultural practices and analytical methods for determining ideal spacing regimes based on the purpose of each plantation.

Field trials conducted with forest species generally occupy large areas, as such species are large individuals (MORAES et al., 2013). This becomes a limiting factor because experiments that occupy large areas are statistically undesirable, as they often do not meet the assumptions for experimentation and are difficult to control (ODA-SOUZA et al., 2008; MORAES et al., 2013). In forestry research, an alternative to random sampling and the use of large experimental areas is utilizing systematic designs, such as those proposed by Nelder (1962).

FLORESTA, Curitiba, PR, v. 51, n. 1, p. 099-108, jan/mar 2021.

Aquino, P. S. R. et.al.

ISSN eletrônico 1982-4688

DOI: 10.5380/rf.v51 i1. 67390 
Therefore, to overcome the limitations inherent to traditional experimental designs, Nelder (1962) proposed an alternative of systematic designs with a continuous quantitative factor, which does not consider the principle of randomization. Among these designs, the systematic "fan-shaped" design is notable and has been applied in several field studies (ODA-SOUZA et al., 2008; MORAES et al., 2013; SANTOS et al., 2017).

This study poses the following hypotheses: (i) narrow spacing favors a rapid increase in height and early mortality, (ii) wide spacing favors a rapid increase in diameter, and (ii) testing a range of spacings may favor detection of this behavior. Therefore, the aim of this study was to assess the effect of spacing on the growth and production variables for juvenile-phase Eucalyptus plants by means of a Nelder (fan-shaped) design.

\section{MATERIALS AND METHODS}

Field research area and implementation of the Nelder "fan-shaped" design

The study was conducted in the Federal District of Brasília at Fazenda Água Limpa (FAL), which has an area of 4,390 ha. The most predominant type of natural vegetation is of the Cerrado biome, particularly the typical Oxisol. The average altitude of the region is $1,100 \mathrm{~m}$, and its geographical coordinates are $15^{\circ} 56^{\prime} 40^{\prime \prime} \mathrm{S}, 47^{\circ} 56^{\prime}$ $52^{\prime}$ W. Based on the Köppen climate classification, the local climate falls into the Aw group: a tropical savanna climate. Average annual rainfall is $1,600 \mathrm{~mm}$, with a pronounced dry season from June to September.

The data used in this study originated from a spacing experiment with hybrid clones of Eucalyptus urophylla S. T. Blake x E. grandis W. Hill ex Maiden (referred to commercially as clone EAC 1528). The spacing experiment was implemented in a Nelder (fan-shaped) design [type "1a", as proposed by Nelder (1962)], characterized by determining the values for the initial radius $r_{0}$ (distance from the central point of the circle to the inner edge); ratio of the geometric progression of the radii, or spacing factor $(\alpha)$; angle between them $(\theta)$; and area $(A i)$ between the plants. Accordingly, the following values were obtained for the Nelder (fan-shaped) design: $r_{0}=$ $2.80 \mathrm{~m}, \alpha=1.11$, and $\theta=10^{\circ}$. Based on these values, the design in the present study was determined, as shown in Table 1 .

Table 1: Planting spacing, area per plant and plant density for 12 treatments in the Nelder (fan-shaped) design Tabela 1: Espaçamento de plantio, área por planta e densidade de plantas no delineamento sistemático tipo "leque".

\begin{tabular}{|c|c|c|c|c|}
\hline \multicolumn{2}{|c|}{ Treatments } & \multirow{2}{*}{$\begin{array}{c}\text { Spacing } \\
\text { between plants } \mathrm{x} \text { between } \\
\text { radius }(\mathrm{m}) \\
0,66 \times 0,49\end{array}$} & \multirow{2}{*}{$\begin{array}{l}\text { Vital Area } \\
\left(\mathrm{m}^{2}\right) \\
0,32\end{array}$} & \multirow{2}{*}{$\begin{array}{r}\begin{array}{r}\text { Plant density } \\
\text { (plants.ha }\end{array} \\
31.250\end{array}$} \\
\hline \multirow{6}{*}{ Narrow } & Inner edge & & & \\
\hline & E1 & $0,80 \times 0,63$ & 0,50 & 20.000 \\
\hline & E2 & $0,96 \times 0,80$ & 0,77 & 12.987 \\
\hline & E3 & $1,17 \times 1,00$ & 1,17 & 8.547 \\
\hline & $\mathrm{E} 4$ & $1,41 \times 1,25$ & 1,76 & 5.682 \\
\hline & E5 & $1,71 \times 1,54$ & 2,64 & 3.788 \\
\hline \multirow{3}{*}{ Intermediate } & E6 & $2,07 \times 1,91$ & 3,94 & 2.538 \\
\hline & E7 & $2,50 \times 2,34$ & 5,86 & 1.706 \\
\hline & E8 & $3,03 \times 2,87$ & 8,69 & 1.151 \\
\hline \multirow{5}{*}{ Wide } & E9 & $3,66 \times 3,51$ & 12,86 & 778 \\
\hline & E10 & $4,43 \times 4,28$ & 19,00 & 526 \\
\hline & E11 & $5,37 \times 5,22$ & 28,03 & 357 \\
\hline & E12 & $6,49 \times 6,35$ & 41,25 & 242 \\
\hline & External edge & $7,85 \times 7,72$ & 60,68 & 165 \\
\hline
\end{tabular}

For better presentation of the results, the treatments were divided into three spacing groups: narrow $(\mathrm{N}$ : treatments E1-5), intermediate (In: treatments E6-8), and wide (W: treatments E9-12). Figure 1 shows the layout for the experiment. The experiment consisted of 12 treatments (arcs) and 36 repetitions (radii/ plants), wherein the individual values per plant constitute a repetition.

The first and the last arc were disregarded, as they constituted the inner edge, with a radius of $2.80 \mathrm{~m}$, and the outer edge, with a radius of $44.26 \mathrm{~m}$. The trial consisted of a circle that made up a circular area of 0.62 ha and a square area of 0.78 ha. Planting consisted of applying 2.5 liters of hydrophilic polymer (hydrogel for planting) to each hole in order to ensure greater survival and sapling development in the summer. 

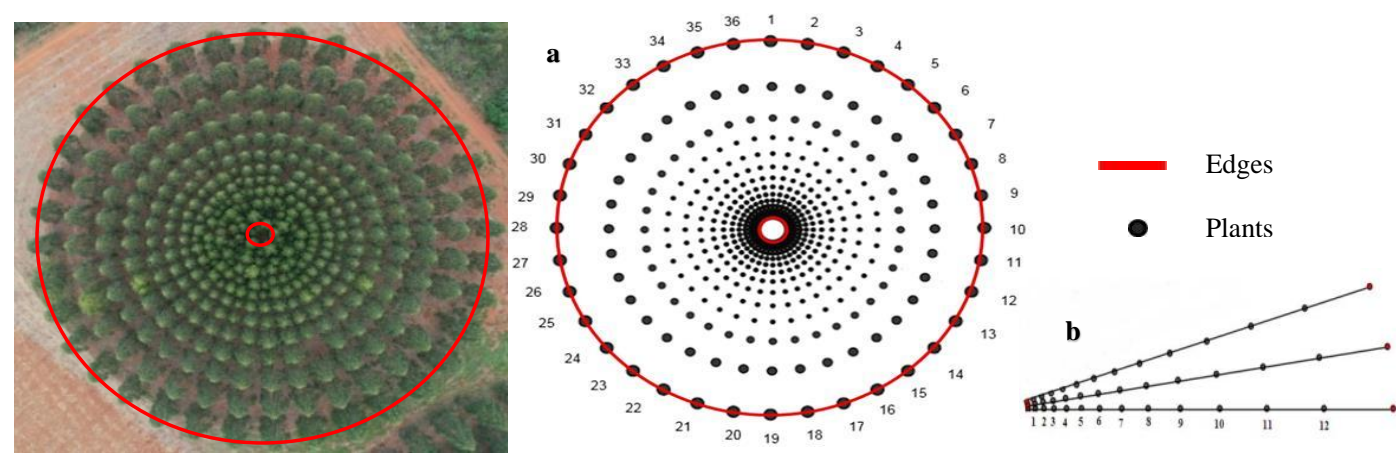

Figure 1: Aerial image of the study area and Design of the installation of the experiment in a Nelder (fan-shaped) design with 12 treatments and 36 repetitions (Figure Autor: Mauro Eloi Nappo).

Figura 1: Foto aérea da área de estudo (a) e Croqui da instalação do experimento em delineamento sistemático tipo "leque" (b) com 12 tratamentos e 36 repetições (Autor: Mauro Eloi Nappo).

\section{Data collection and analysis}

The experiment was assessed at 16, 24, and 36 months. All plants were identified by means of numbered aluminum plates attached to the trunk. Individual data on the diameter at breast height (DBH) and total height $(\mathrm{H})$ of all the living plants were measured with a caliper and a clinometer, respectively. Occurrences of plant defects and mortality were also evaluated. To obtain the solid volume for each plant, the volume of the standing trees was determined by measuring the diameter in sections of $0.5 \mathrm{~m}$ from the base (ground level) to a height of 5 meters and calculating the volume for each section by Smalian's formula, and limb and branch volume was calculated as a regular cone, as described by Andrade (2017). The volume was measured for five plants per treatment, totaling 60 individuals. Selection of the trees in order to attain volume was based on the average diameter $(q)$ calculated for each treatment, according to Equation (1). Thus, the five trees that presented a value equal to or closest to $q$ were selected for the treatment.

$$
q=\sqrt{n^{-1}} \sum_{i=1}^{n} D B H_{i}^{2}
$$

Where: $q$ is the quadratic mean diameter, $\mathrm{DBH}$ is the diameter at breast height at $1.30 \mathrm{~m}$, and $n$ is the number of trees.

Prior to planting, post-emergent herbicide was applied to the total area and pre-emergent herbicide was applied to the subsoil to control competition. Subsequently, competition was controlled manually throughout the total area until crown closure, when competition control became cultural due to the shade.

Precipitation and temperature are important factors in plant survival, especially in the early planting stages. Accordingly, monthly meteorological data on average air temperature and precipitation were obtained. The monthly averages used in the study were visually compared to the Climate Normals of the Federal District of Brasília from 1961 to 1990 to observe the incidence of any atypical events, such as a prolonged drought. These data were obtained from the weather station located at FAL.

A descriptive statistical analysis of the data for the variables $\mathrm{H}$ and $\mathrm{DBH}$ determined the mean, maximum, and minimum values, coefficient of variation $(\mathrm{CV} \%)$, and standard error of the mean. Pearson's correlation coefficient $(r)$ was calculated for the dendrometric variables in the vital area for each plant. Levene's test was applied to attain the homogeneity of variances. After finding homogeneity, analysis of variance was calculated (Ftest at the 5\% level of significance), categorizing the experiment as a completely randomized design (CRD), followed by a comparative analysis of the means with the Scott-Knott cluster test. Where there was no homogeneity of variances, the non-parametric Kruskal-Wallis test at the 5\% level of significance was applied. It is worth noting that traditional statistical analyses, such as ANOVA, are not commonly recommended for experiments conducted with systematic designs, as the arrangement of plants is not randomized; the lack of randomness in the experimental trial, in theory, does not guarantee the independence of associated errors, which can draw correlations between experimental units (MORAES et al., 2013). However, a previous spatial assessment (utilizing geostatistical analysis) of the same area for field research (data undisclosed) found that the data did not demonstrate spatial dependence in the juvenile phase. This confers reliability to the application of classical statistics, as the variable's randomness (the assumption for the independence of errors) has been met, and the results will not be biased for the ages observed. 


\section{RESULTS}

The data for total precipitation and average monthly temperature as well as the Climate Normals for the Federal District of Brasília from 1961 to 1990 are shown in Figure 2. Table 2 includes the results for survival, average monthly increases, and Pearson's correlation coefficient $(r)$.

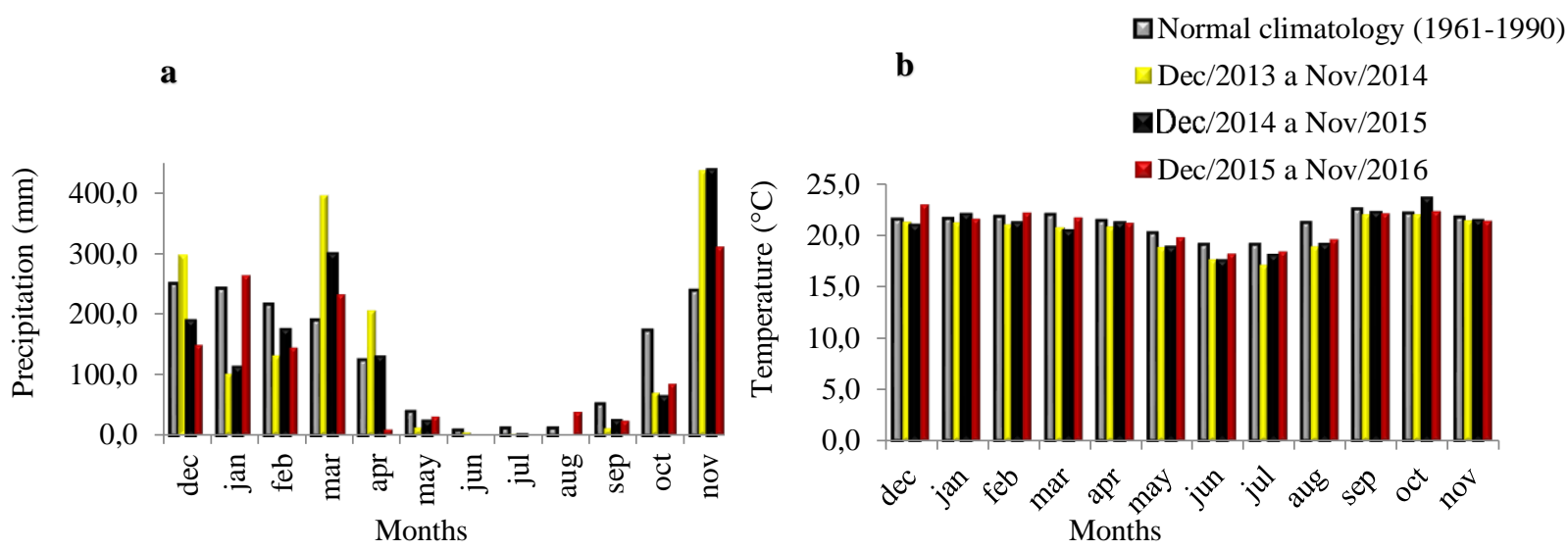

Figure 2: Monthly and mean total precipitation of 30 years of data (1961-1990) (a) and average monthly and average temperature of 30 years of data (b) in Brasília, DF.

Figura 2: Precipitação total mensal e média de 30 anos de dados (1961-1990) (a) e temperatura média mensal e média de 30 anos de dados (b) em Brasília, DF.

Table 2: Monthly mean increments (MMI), percentage of tree survival in each treatment at 16, 24 and 36 months and mean monthly and Pearson's correlation coefficient $(r)$ values of the variables total height and DBH with the vital area variable.

Tabela 2: Incrementos médio mensais (IMM), porcentagem de sobrevivência das árvores em cada tratamento aos 16, 24 e 36 meses e valores dos coeficientes de correlação linear de Pearson $(r)$ das variáveis altura total e DAP com a variável área vital.

\begin{tabular}{|c|c|c|c|c|c|c|c|}
\hline & \multirow[t]{2}{*}{ Tratament } & \multirow{2}{*}{$\begin{array}{c}\text { Area } \\
\left(\mathrm{m}^{2}\right)\end{array}$} & \multicolumn{3}{|c|}{ Survival (\%) } & \multirow{2}{*}{$\begin{array}{c}\text { MMI H } \\
(\mathrm{m})\end{array}$} & \multirow{2}{*}{$\begin{array}{l}\text { MMI DBH } \\
\quad(\mathrm{cm})\end{array}$} \\
\hline \multirow{6}{*}{$\mathrm{N}$} & & & 16 months & 24 months & 36 months & & \\
\hline & E1 & 0,50 & 94 & 81 & 64 & 0,30 & 0,13 \\
\hline & $\mathrm{E} 2$ & 0,77 & 100 & 97 & 83 & 0,38 & 0,19 \\
\hline & E3 & 1,17 & 100 & 100 & 94 & 0,41 & 0,22 \\
\hline & E4 & 1,76 & 100 & 100 & 100 & 0,44 & 0,26 \\
\hline & E5 & 2,64 & 100 & 100 & 100 & 0,45 & 0,29 \\
\hline \multirow[t]{4}{*}{ In } & E6 & 3,94 & 97 & 97 & 97 & 0,46 & 0,32 \\
\hline & E7 & 5,86 & 100 & 100 & 100 & 0,47 & 0,35 \\
\hline & E8 & 8,69 & 100 & 100 & 100 & 0,46 & 0,37 \\
\hline & E9 & 12,86 & 97 & 97 & 97 & 0,45 & 0,37 \\
\hline \multirow{3}{*}{$\mathrm{W}$} & E10 & 19,00 & 100 & 100 & 100 & 0,43 & 0,39 \\
\hline & E11 & 28,01 & 97 & 97 & 97 & 0,41 & 0,40 \\
\hline & E12 & 41,25 & 97 & 97 & 97 & 0,38 & 0,40 \\
\hline$r(\mathrm{H} \times \mathrm{Area})$ & & & $-0,60 *$ & $-0.32 *$ & $-0,12^{*}$ & & \\
\hline$r(\mathrm{DBH} \times \mathrm{Area})$ & & & $0,45^{*}$ & $0,54^{*}$ & $0,66^{*}$ & & \\
\hline
\end{tabular}

Where: $\mathrm{N}=$ Narrow; In = Intermediate e; $\mathrm{W}=\mathrm{Wide}$; $\mathrm{ns}=$ not significant; $*$ = Significant at $5 \% . \mathrm{H}=$ total height; $\mathrm{DBH}=$ diameter at breast height; $\mathrm{MMI}=$ Monthly mean increments

The average survival rate in the experiment was $99 \%, 97 \%$, and $94 \%$ at 16, 24, and 36 months, respectively. In the first year, treatment E1 presented a defect and a death, and E6, E9, E11, and E12 each presented a defect. In the third year, treatments E1, E2, and E3 had 11, 5, and 2 deaths, respectively. These results indicated that all the mortalities occurred only in treatments with narrow spacing, evidencing the presence of competition.

Table 3 displays the results of the descriptive statistics for the variables DBH and $\mathrm{H}$. The different spacing treatments showed statistically significant differences for $\mathrm{DBH}$ and $\mathrm{H}$, as verified by the $p$-values for the F-test

FLORESTA, Curitiba, PR, v. 51, n. 1, p. 099-108, jan/mar 2021.

Aquino, P. S. R. et.al.

ISSN eletrônico 1982-4688

DOI: $10.5380 /$ rf.v51 i1. 67390 
(16 and 24 months) and the Kruskal-Wallis test (36 months). In the three ages observed, the DBH averages showed a clear proportional response to spacing.

Table 3: Descriptive statistics for the DBH and total height $(\mathrm{H})$ at different spacings.

Tabela 3: Estatísticas descritivas para as variáveis DAP e altura total $(\mathrm{H})$ nos diferentes espaçamentos.

\begin{tabular}{|c|c|c|c|c|c|c|c|c|c|c|c|}
\hline $\begin{array}{c}\text { Age } \\
\text { (months) }\end{array}$ & Trat & $\begin{array}{c}\text { DBH } \\
\text { min }\end{array}$ & $\begin{array}{c}\text { DBH } \\
\text { max }\end{array}$ & Ave* & Std & CV\% & $\begin{array}{c}\mathbf{H} \\
\min \end{array}$ & $\begin{array}{c}\mathbf{H} \\
\max \\
\end{array}$ & Ave* & Std & CV\% \\
\hline \multirow{12}{*}{16} & E1 & 2,0 & 6,2 & $3,8 \mathrm{a}$ & 0,757 & 19,9 & 6,5 & 9,6 & $8,4 a$ & 0,800 & 9,5 \\
\hline & E2 & 3,1 & 5,9 & $4,6 b$ & 0,667 & 14,3 & 6,5 & 10,0 & $8,9 b$ & 0,815 & 9,1 \\
\hline & E3 & 2,9 & 7,0 & $5,3 c$ & 0,807 & 15,1 & 6,8 & 10,2 & $9,3 b$ & 0,728 & 7,8 \\
\hline & E4 & 2,0 & 7,1 & $6,0 \mathrm{~d}$ & 0,894 & 15,0 & 5,0 & 10,8 & $10,0 \mathrm{c}$ & 0,953 & 9,5 \\
\hline & E5 & 3,7 & 7,3 & $6,5 \mathrm{e}$ & 0,840 & 12,9 & 7,5 & 11,5 & $10,2 \mathrm{c}$ & 0,924 & 9,1 \\
\hline & E6 & 2,0 & 8,3 & $7,0 \mathrm{f}$ & 1,076 & 15,3 & 4,5 & 11,5 & $10,1 \mathrm{c}$ & 1,109 & 11,0 \\
\hline & E7 & 5,9 & 8,3 & $7,5 \mathrm{~g}$ & 0,515 & 6,9 & 8,2 & 10,8 & $9,8 \mathrm{c}$ & 0,600 & 6,1 \\
\hline & E8 & 5,2 & 8,9 & $7,6 \mathrm{~g}$ & 0,681 & 8,9 & 6,0 & 10,2 & $9,2 \mathrm{~b}$ & 0,737 & 8,0 \\
\hline & E9 & 4,2 & 8,4 & $7,5 \mathrm{~g}$ & 0,839 & 11,2 & 7,0 & 9,7 & $8,5 \mathrm{a}$ & 0,552 & 6,5 \\
\hline & E10 & 5,5 & 9,7 & $7,7 \mathrm{~g}$ & 0,914 & 11,9 & 7,4 & 9,1 & $8,2 \mathrm{a}$ & 0,480 & 5,8 \\
\hline & E11 & 6,3 & 9,2 & $7,7 \mathrm{~g}$ & 0,667 & 8,7 & 6,9 & 9,0 & $7,9 \mathrm{~d}$ & 0,514 & 6,5 \\
\hline & E12 & 3,8 & 8,6 & $\begin{array}{c}7,0 f \\
p=0,00\end{array}$ & 1,086 & 15,4 & 5,0 & 8,5 & $\begin{array}{c}7,3 \mathrm{e} \\
\mathrm{p}=0,00\end{array}$ & 0,733 & 9,9 \\
\hline \multirow{12}{*}{24} & E1 & 3,5 & 8,1 & $4,3 \mathrm{a}$ & 0,869 & 19,9 & 7,9 & 12,6 & $10,0 \mathrm{a}$ & 1,130 & 11,3 \\
\hline & E2 & 3,2 & 7,3 & $5,6 b$ & 1,077 & 19,3 & 7,2 & 13,5 & $11,1 b$ & 1,276 & 11,5 \\
\hline & E3 & 3,3 & 8,3 & $6,6 c$ & 1,056 & 16,1 & 7,4 & 14,0 & $11,8 \mathrm{c}$ & 1,251 & 10,6 \\
\hline & E4 & 2,0 & 8,9 & $7,5 d$ & 1,200 & 16,0 & 4,7 & 14,3 & $12,6 \mathrm{~d}$ & 1,561 & 12,4 \\
\hline & E5 & 4,0 & 10,1 & $8,3 \mathrm{e}$ & 1,234 & 14,9 & 8,9 & 15,4 & $13,1 d$ & 1,287 & 9,8 \\
\hline & E6 & 2,5 & 10,4 & $9,2 \mathrm{f}$ & 1,340 & 14,6 & 4,7 & 15,7 & $13,8 \mathrm{e}$ & 1,716 & 12,4 \\
\hline & E7 & 8,1 & 11,7 & $10,2 \mathrm{~g}$ & 0,666 & 6,5 & 12,5 & 15,7 & $14,2 \mathrm{e}$ & 0,661 & 4,7 \\
\hline & E8 & 7,3 & 11,9 & $10,6 \mathrm{~h}$ & 0,849 & 8,0 & 10,0 & 16,7 & $13,8 \mathrm{e}$ & 0,987 & 7,1 \\
\hline & E9 & 8,0 & 11,5 & $10,5 \mathrm{~h}$ & 0,804 & 7,6 & 11,9 & 14,4 & $12,9 \mathrm{~d}$ & 0,728 & 5,6 \\
\hline & E10 & 8,5 & 12,0 & $10,6 \mathrm{~h}$ & 0,873 & 8,2 & 10,7 & 13,8 & $12,1 \mathrm{c}$ & 0,789 & 6,5 \\
\hline & E11 & 8,5 & 13,0 & $10,8 \mathrm{~h}$ & 0,910 & 8,4 & 10,35 & 12,7 & $11,4 \mathrm{~b}$ & 0,685 & 6,0 \\
\hline & E12 & 5,2 & 11,5 & $\begin{array}{c}9,9 \mathrm{~g} \\
\mathrm{p}=0,00\end{array}$ & 1,350 & 13,6 & 7,3 & 12,1 & $\begin{array}{c}10,1 \mathrm{a} \\
\mathrm{p}=0,00\end{array}$ & 0,954 & 9,4 \\
\hline \multirow[b]{13}{*}{ Kruskal w } & E1 & 3,5 & 10,8 & 4,7 & 1,390 & 29,3 & 9,1 & 16,6 & $10,9 a$ & 1,533 & 14,1 \\
\hline & $\mathrm{E} 2$ & 4,2 & 9,5 & 6,9 & 1,540 & 22,4 & 10,2 & 16,6 & $13,7 \mathrm{a}$ & 1,990 & 14,6 \\
\hline & E3 & 4,3 & 11,0 & 8,0 & 1,551 & 19,4 & 9,4 & 16,9 & $14,6 b$ & 1,72 & 11,7 \\
\hline & E4 & 2,0 & 11,3 & 9,3 & 1,570 & 16,9 & 5,0 & 17,2 & $15,8 \mathrm{c}$ & 2,016 & 12,7 \\
\hline & E5 & 4,4 & 12,9 & 10,4 & 1,776 & 17,1 & 9,8 & 17,5 & $16,3 d$ & 1,879 & 11,5 \\
\hline & E6 & 2,7 & 13,0 & 11,6 & 1,772 & 15,3 & 5,6 & 17,6 & $16,7 \mathrm{e}$ & 1,989 & 11,9 \\
\hline & E7 & 10,1 & 13,8 & 12,5 & 0,790 & 6,3 & 15,4 & 17,7 & $17,0 \mathrm{e}$ & 0,505 & 3,0 \\
\hline & E8 & 10,2 & 15,0 & 13,2 & 0,914 & 6,9 & 14,0 & 17,9 & $16,7 \mathrm{e}$ & 0,803 & 4,8 \\
\hline & E9 & 10,6 & 15,4 & 13,4 & 0,947 & 7,1 & 15,0 & 17,4 & $16,1 \mathrm{~d}$ & 0,778 & 4,8 \\
\hline & E10 & 11,2 & 16,0 & 14,1 & 1,081 & 7,7 & 14,3 & 17,4 & $15,6 c$ & 0,845 & 5,4 \\
\hline & E11 & 12,0 & 17,0 & 14,6 & 1,013 & 7,0 & 13,6 & 16,5 & $14,8 \mathrm{~b}$ & 0,825 & 5,6 \\
\hline & E12 & 8,2 & 16,5 & 14,4 & 1,841 & 12,8 & 10,1 & 15,6 & $13,7 \mathrm{a}$ & 1,024 & 7,5 \\
\hline & llis & & & $\mathrm{p}=0,00$ & & & & & $\mathrm{p}=0,00$ & & \\
\hline
\end{tabular}

This pattern of proportional growth of $\mathrm{DBH}$ as a function of the vital area was also confirmed by the value of $r$ given by Pearson's correlation coefficient (Table 2). The highest DBH averages at 16 and 24 months were observed in both the intermediate and the wide spacings. At 36 months, however, the highest DBH averages were constrained to the wide spacing treatments (E10, E11, and E12) and did not differ among one another in the cluster analysis of averages (Table 3).

Spacing was found to have the most influence on height growth at the age of 16 months (Table 3), with the lowest height averages recorded for the treatments with the widest spacing. This inverse relation between height growth and the vital area was also confirmed by the $r$ value of Pearson's correlation coefficient (Table 2). The influence of spacing on height growth decreased after 24 and 36 months of age. Similarities were observed in

FLORESTA, Curitiba, PR, v. 51, n. 1, p. 099-108, jan/mar 2021.

Aquino, P. S. R. et.al.

ISSN eletrônico 1982-4688

DOI: $10.5380 /$ rf.v51 i1. 67390 
the averages for $\mathrm{H}$ in the narrow spacing and the wide spacing treatments, especially at the two extreme treatments (E1 and E12), which did not differ from each other in the cluster analysis of averages. (Table 3).

Table 4 provides the values for the average volumetric yield per hectare $\left[\mathrm{V}\left(\mathrm{m}^{3} \cdot \mathrm{ha}^{-1}\right)\right]$ and per plant $[\mathrm{V}$ $\left(\mathrm{m}^{3}\right.$. plant $\left.\mathrm{t}^{-1}\right)$ ] for each treatment. Figure 4 shows the progress of production throughout the period. Narrow spacing treatments were found to provide greater volumetric yield per hectare than that of wider spacing treatments, and wider spacing treatments provided greater individual volume than that of narrow spacing treatments.

Table 4: Average volumetric yield per hectare and plant at 16, 24 and 36 months at different spacings, discounting mortality.

Tabela 4: Produção média por hectare e por planta aos 16, 24 e 36 meses nos diferentes espaçamentos, descontando-se a mortalidade.

\begin{tabular}{lccccccc}
\hline Trat. & Area $\left(\mathrm{m}^{2}\right)$ & \multicolumn{2}{c}{16 months } & \multicolumn{2}{c}{24 months } & \multicolumn{2}{c}{36 months } \\
\hline & & $\begin{array}{c}\mathrm{V} \\
\left(\mathrm{m}^{3} \cdot \mathrm{plant}^{-1}\right)\end{array}$ & $\begin{array}{c}\mathrm{V} \\
\left(\mathrm{m}^{3} \cdot \mathrm{ha}^{-1}\right)\end{array}$ & $\begin{array}{c}\mathrm{V} \\
\left(\mathrm{m}^{3} \cdot \mathrm{plant}^{-1}\right)\end{array}$ & $\begin{array}{c}\mathrm{V} \\
\left(\mathrm{m}^{3} \cdot \mathrm{ha}^{-1}\right)\end{array}$ & $\begin{array}{c}\mathrm{V} \\
\left(\mathrm{m}^{3} \cdot \mathrm{plant}^{-1}\right)\end{array}$ & $\begin{array}{c}\mathrm{V} \\
\left(\mathrm{m}^{3} \cdot \mathrm{ha}^{-1}\right)\end{array}$ \\
\hline E1 & 0,50 & 0.006766 & 109,61 & 0.007944 & 128,70 & 0.008163 & 132,24 \\
E2 & 0,77 & 0.009856 & 124,15 & 0.013678 & 172,30 & 0.018008 & 226,86 \\
E3 & 1,17 & 0.013887 & 118,69 & 0.021278 & 181,86 & 0.035074 & 299,78 \\
E4 & 1,76 & 0.017719 & 100,67 & 0.027636 & 157,03 & 0.046766 & 265,71 \\
E5 & 2,64 & 0.019502 & 73,87 & 0.033630 & 127,39 & 0.061839 & 234,24 \\
E6 & 3,94 & 0.023440 & 57,71 & 0.044716 & 110,08 & 0.077755 & 191,42 \\
E7 & 5,86 & 0.023771 & 40,57 & 0.051469 & 87,83 & 0.092007 & 157,01 \\
E8 & 8,69 & 0.023173 & 26,67 & 0.053015 & 61,01 & 0.093065 & 107,09 \\
E9 & 12,86 & 0.019615 & 14,80 & 0.050506 & 38,11 & 0.098125 & 74,05 \\
E10 & 19,00 & 0.020241 & 10,65 & 0.050468 & 26,56 & 0.109570 & 57,67 \\
E11 & 28,01 & 0.018591 & 6,44 & 0.045336 & 15,70 & 0.108526 & 37,58 \\
E12 & 41,25 & 0.016038 & 3,76 & 0.037929 & 8,90 & 0.096094 & 22,56 \\
\hline
\end{tabular}

Trat. $=$ tratament; $\mathrm{V}=$ average volumetric yield

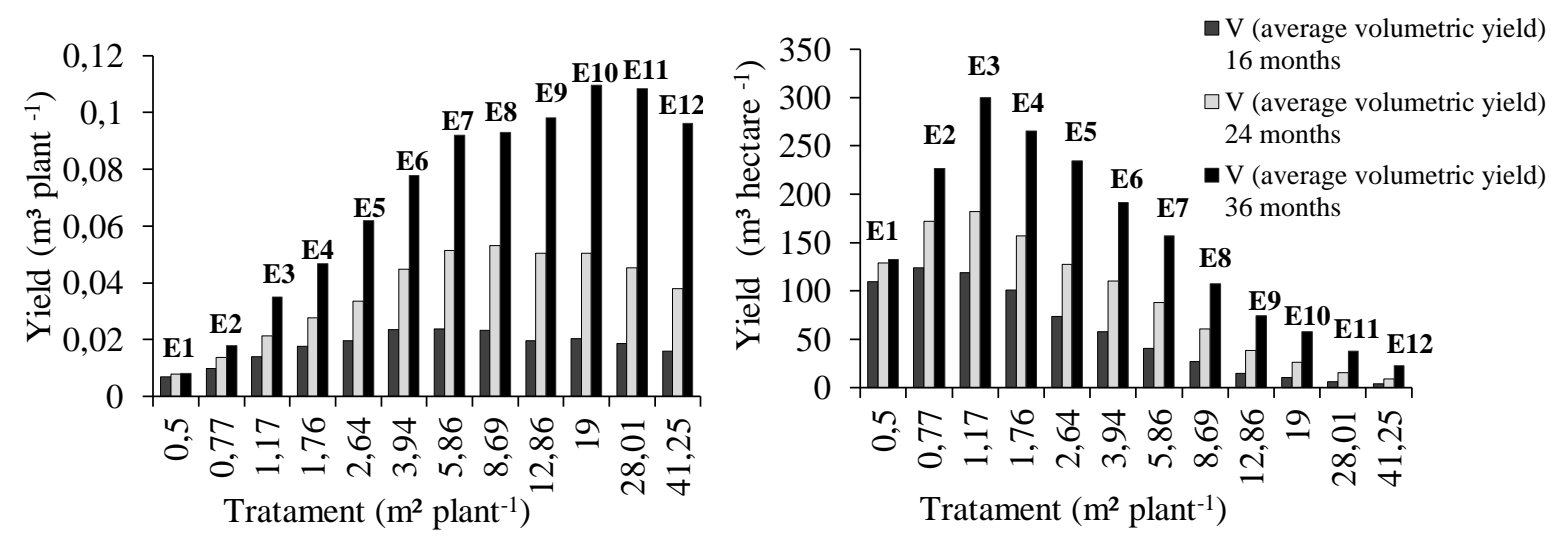

Figure 4: Average volumetric yield per plant and per hectare, discounting mortality at different spacings.

Figura 4: Volume médio por planta e por hectare descontando a mortalidade nos diferentes espaçamentos.

\section{DISCUSSION}

\section{Survival}

Based on a visual assessment of the graphs for total precipitation and average monthly temperatures, no atypical climatic events were noted in the temperature data. The precipitation data demonstrated a slight variation, especially in the months of March and November and predominantly in the first and second years of the study. There was a greater amount of precipitation in these months than the data on the climate normal (Figure 2a). This may have favored the early development of the individuals, which could be observed in the average monthly increases in total height $(\mathrm{H})$ and diameter $(\mathrm{DBH})$ (Table 2). These results corroborate with reports by Miranda $e t$ al. (2015) on the average precipitation's effect on the average height growth of dominant trees as a function of age. The authors found that the average height growth of dominant trees was higher in regions with more precipitation. Additionally, Stape et al. (2010) found that precipitation is one of the main factors influencing

FLORESTA, Curitiba, PR, v. 51, n. 1, p. 099-108, jan/mar 2021.

Aquino, P. S. R. et.al.

ISSN eletrônico 1982-4688

DOI: 10.5380/rf.v51 i1. 67390 
eucalyptus productivity. Further, according to Resquin et al. (2019), rainfall regime, along with proper soil preparation, can contribute to attaining high levels of survival in the early planting stages of some eucalyptus species. The low occurrence of defects found in this study can also be attributed to the use of hydrogel in the planting holes, which reduces the loss of moisture and nutrients due to leaching and contributes to the development of the root system and to plant growth and development (NAVROSKI et al., 2015; FELIPPE et al., 2016). For mortality, all deaths had occurred only in the treatments with narrow spacing. Therefore, the mortality observed in the study can be classified as regular, as it was a consequence of competition, which Lee (1971) states is more intense in dense or overstocked stands.

\section{Growth in diameter and total height}

Treatment E1 $\left(0.50 \mathrm{~m}^{2}\right)$ presented the highest CV\% (19.9\% and $\left.29.3 \%\right)$ for the DBH variable across the three years of the study (Table 3 ). This same pattern was observed for the $\mathrm{H}$ variable at 36 months; thus, narrow spacing $\left(0.50 \mathrm{~m}^{2}\right.$ to $\left.2.64 \mathrm{~m}^{2}\right)$ resulted in higher $\mathrm{CV} \%$ values than those recorded for the intermediate and wide spacing treatments (Table 3). This behavior may be associated with the increase in suppressed plants and the high mortality rate that occurred in Treatment $1\left(0.50 \mathrm{~m}^{2}\right)$ (Table 2) due to competition, which is a characteristic of narrow plant spacing (LEE, 1971; GADOW; KOTZE, 2014). The intensification of competition for vital resources means that narrow plant spacing reaches site capacity in a short period of time with a decrease in the dimensions of the products obtained as compared to that of wide plant spacing (ASSMANN, 1970). This imposes greater pressure for survival and creates different strata of crown heights in the stand, wherein there are individuals of dominant, intermediate, and suppressed crown classes. Furthermore, Schneider et al. (2015) maintains that most species of eucalyptus are intolerant to competition; a rapid segregation into strata occurs depending on spacing, species, site quality, and the interaction of these factors. Both suppression and mortality cause changes in the vital area available to the adjacent plants, in that more available space acts in their favor. Consequently, these plants present increased development which then causes more uneven growth, thus increasing the values for CV\%.

DBH had a proportional growth response to the available vital area. In general, the results align with those reported in other studies. Wider plant spacing generally induces more rapid diameter growth than narrow plant spacing in the first years of growth (REINER et al., 2011; BENIN et al., 2014). Reiner et al. (2011) observed this proportional effect (vital area/DBH) in E. dunnii trees from the age of three years. In the present study, the proportional effect was observed after 16 months. It is important to note that early detection of the effect of spacing on DBH growth may be related to the range of tested spacings, which possibly favored detection of this behavior. This highlights the efficiency of the Nelder (fan-shaped) design, as it was possible to observe the aforementioned behavior within a short period of time (16 months) and a small physical space (experimental area $=0.62$ hectares). These results revealed that the available space for growth affects diameter growth in forest species, as also observed by Neto et al. (2010) and Nascimento et al. (2012). In forest stands, the useful area of a tree can be restricted by adjacent plants, thereby generating competition between roots and crowns, which in turn can influence diameter growth (HILEY, 1959).

Like the diameter, total height growth was also influenced by different spacings, especially at 16 months (Tables 2 and 3). These results corroborate with those of several studies which reported the effect of spacing on the rate of total height growth for forest plant species (LEITE et al., 1997; LELES et al., 2014). At 36 months, similarities were observed in the averages of $\mathrm{H}$ for narrowing spacing treatments (except for E1) and wide spacing treatments (Table 3). These results indicated that narrow spacing induced rapid height growth in the first year, which was attributed to the initial competition (light, water, nutrients, etc.) they had undergone. Nevertheless, the growth rate in $\mathrm{H}$ decreased at 36 months. Moreover, the correlation between the vital area and height growth gradually decreased with each assessment and presented a very low yet significant value for $r$ at 36 months (Table 2). The highest increases in height were observed in the intermediate spacing treatments after 24 months, particularly in the E7 treatment $\left(5.86 \mathrm{~m}^{2}\right)$, indicating that these treatments had the best initial development (Table $3)$. It is worth mentioning that the two extreme treatments $\left(0.50 \mathrm{~m}^{2}\right.$ and $\left.41.25 \mathrm{~m}^{2}\right)$ at 36 months presented the lowest incremental values for average height. This may indicate that the narrow spacing in treatment E1 contributed to the decreased rate of height growth as a result of the extreme competition undergone by the individuals. For treatment E12 $\left(41.25 \mathrm{~m}^{2}\right)$, there may have been an absence of competition for resources which failed to stimulate height growth as seen in the other treatments. In general, the conventional spacing ( $3 \mathrm{~m} \mathrm{x} 2 \mathrm{~m}$, $3 \mathrm{~m} \times 1.5 \mathrm{~m}$, and $3 \mathrm{~m} \times 3 \mathrm{~m}$ ) for plantations of forest species either does not affect or barely affects the $\mathrm{H}$ variable. This was also observed in the present study, as the intermediate spacing treatments $\left(3.94 \mathrm{~m}^{2}, 5.86 \mathrm{~m}^{2}\right.$, and 8.69 $\mathrm{m}^{2}$ ), which have a vital area similar to that of the conventional spacing, showed little variation in the average $\mathrm{H}$ values (Table 3). Reiner et al. (2011) evaluated the growth dynamics of $E$. dunnii in different spacings, some of which were conventional, and did not observe any significant differences in plant height at 12 and 24 months.

FLORESTA, Curitiba, PR, v. 51, n. 1, p. 099-108, jan/mar 2021. 


\section{Production by volume}

At 16 and 24 months, the highest volumetric yield per plant occurred in the intermediate spacing treatments E7 and E8, whereas the narrow spacing treatments yielded the lowest individual productivity. However, at 36 months, wide spacing treatments registered the highest individual volumetric yield, especially in treatments E10 and E11 (Figure 4). It is important to highlight that the plants in the intermediate spacing treatments exhibited very similar results, which reinforces that the range of tested treatments is crucial to detecting the influence of the vital area on volumetric yield. A study by Cardoso et al. (2013) found no significant difference in the volume of Pinus taeda L. at the end of a 24-year cycle across various tested spacings. However, the spacings tested by the authors closely resemble the treatments E6 to E9 $\left(3.94 \mathrm{~m}^{2}\right.$ to $\left.12.86 \mathrm{~m}^{2}\right)$ of this study, which presented very similar values. It is noteworthy that at 36 months, the treatment with the widest spacing, E12 $\left(41.25 \mathrm{~m}^{2}\right)$, presented an average volume per plant that is very similar to the volumes presented in intermediate spacing treatments (E7 and E8) (Table 4), which exhibited a much higher volumetric yield per hectare as a function of greater plant density. Thus, there will be no increase in production if spacing is so wide that the available resources exceed the plant's physiological capacity of assimilation, whereby the area becomes underutilized (SCHNEIDER et al., 1998; ETIGALE et al., 2014). However, the results of this study refer only to data on initial growth and cannot conclude that the widest spacing tested will lead to underutilization of the area in the future. Age appears to be an important factor; wider spacing tends to provide greater volume per plant with age (Figure 4). Similar results were found by Reiner et al. (2011) and Cardoso et al. (2013); high plant densities generate a higher volumetric yield per hectare and a lower volumetric yield per individual. Leite et al. (1997) reinforces that wider spacing in eucalyptus forests is expected to generate a greater volumetric yield per individual.

At 36 months, the highest volumetric yield per hectare was found in treatments with narrow spacing, particularly in treatments E3, E4, and E5. The treatment of $0.50 \mathrm{~m}^{2}(\mathrm{E} 1)$ stagnated and declined due to the excessive competition that was established during the early phases of growth. Higher plant density meant that the treatments with narrow spacing had the highest volumetric yield per hectare (Figure 4b). In contrast, interspecific competition starts early, which can cause unevenness in the plants due to differences in tree extracts and the increases in mortality rate (ASSMANN, 1970).

Even though the yield per hectare was inversely proportional to density, it is worth noting that at 36 months, treatments E1 and E2 $\left(0.50 \mathrm{~m}^{2}\right.$ and $\left.0.77 \mathrm{~m}^{2}\right)$ yielded a lower productivity per area than that of treatment E3 $\left(1.17 \mathrm{~m}^{2}\right)$, which, although less dense, had a larger area per plant. This can be attributed to the increased incidence of mortality and suppressed plants due to competition in narrow spacings (FAN et al., 2017), which reduces productivity. Notwithstanding, Balloni and Simões (1980) found that, even with a higher percentage of plant defects and suppressed plants, reduced spacing allows a greater total volume of wood per area as well as a greater number of trees for the second rotation, which is a desirable situation in coppicing systems, for example.

\section{CONCLUSIONS}

- The dendrometric variables in question were affected by different spacings in the juvenile phase of eucalyptus plants.

- The spacing of $1.17 \mathrm{~m}$ x $1.00 \mathrm{~m}$ (E3) demonstrated the highest volumetric yield per hectare at 36 months.

- Despite having a smaller vital area, the spacings of $2.50 \mathrm{~m}$ x $2.34 \mathrm{~m}$ (E7) and $3.03 \mathrm{~m}$ x $2.87 \mathrm{~m}$ (E8) presented a volumetric yield per plant equal to that of the spacing of $6.49 \mathrm{~m} \mathrm{x} 6.35 \mathrm{~m} \mathrm{(E12).}$

\section{REFERÊNCES}

ANDRADE, V. C. L. D. Modelos Volumétricos de Dupla Entrada para Aplicar em Povoamentos Florestais Brasileiros. Floresta e Ambiente, v. 24, 2017.

ASSMANN, E. The principles of forest yield study. Oxford: Pergamon, 1970, 506 p.

BALLONI, E. A.; SIMÕES, J. W. O espaçamento de plantio e suas implicações silviculturais. IPEF (Série Técnica, v. 3, p. 1-26, 1980.

BENIN, C. C.; WIONZEK, F. B.; WATZLAWICK, L. F. Initial assessments on the plantation of Eucalyptus benthamii Maiden et Cambage deployed in different spacing. Applied Research \& Agrotechnology, v. 7, n.1, p. 55-61, 2014.

CARDOSO, D. J.; LACERDA, A. E. B.; ROSOT, M. A. D.; GARRASTAZÚ, M. C.; LIMA, R. T. Influence of spacing regimes on the development of loblolly pine (Pinus taeda L.) in Southern Brazil. Forest Ecology and Management, v. 310, p. 761-769, 2013.

FLORESTA, Curitiba, PR, v. 51, n. 1, p. 099-108, jan/mar 2021. 
CARON, B.O.; ELOY, E.; SOUZA, V.Q.; SCHMIDT, D.; BALBINOT, R.; BEHLING, A.; MONTEIRO, G.C. Quantificação da Biomassa florestal em plantios de curta rotação com diferentes espaçamentos. Comunicata Scientiae, v.6, n.1, p.106-112, 2015.

ETIGALE, E. B., AJAYI, S., UDOFIA, S. I., \& MOSES, M. U. Assessment of Stand Density and Growth Rate of Three Tree Species in an Arboretum within the University of Uyo, Nigeria. Journal of Research in Forestry, Wildlife and Environment, v. 6, n. 1, p. 8-16, 2014.

FAN, C.; TAN, L.; ZHANG, P.; LIANG, J.; ZHANG, C.; WANG, J.; ZHAO, X.; von GADOW, K. Determinants of mortality in a mixed broad-leaved Korean pine forest in northeastern China. European journal of forest research, v. 136, n.3, p. 457-469, 2017.

FELIPPE, D.; NAVROSKI, C. M.; SAMPIETRO, J. A.; FRIGOTTO, T.; ALBUQUERQUE, J. A.; MOTA, C. S.; PEREIRA, M. O. Efeito do hidrogel no crescimento de mudas de Eucalyptus benthamii submetidas a diferentes frequências de irrigação. Floresta, v. 46, n. 2, p. 215-225, 2016.

GADOW, K.V.; KOTZÉ, H. Tree survival and maximum density of planted forests-observations from South African Spacing Studies. Forest Ecosyst, v. 1, p. 1-9, 2014.

HILEY, W. E. Conifers: South African methods of cultivation. London, Faber and Faber, 1959, 123 p.

LEE, Y. Predicting mortality for even-aged stands of lodgepole pine. Forestry Chronicle, v. 47, n. 1, p 29-32, 1971.

LEITE, F. P. BARROS, N. D.; NOVAIS, R. D.; SANS, L. M. A.; FABRES, A. S. Crescimento de Eucalyptus grandis em diferentes densidades populacionais. Revista Árvore, v. 21, n. 3, p. 313-321, 1997.

LELES, P. S. dos S.; MACHADO, T. F. F.; ALONSO, J. M.; DE ANDRADE; A. M., SILVA; L. L. da. Crescimento e Biomassa de Melia azedarach L. em Diferentes Espaçamentos e Características Tecnológicas da Madeira Visando à Produção de Carvão. Floresta e Ambiente, v. 21, n. 2, p. 214-223, 2014.

MIRANDA, R. O. V.; DIAS, A. N.; FIGUEIREDO FILHO, A.; SOARES, I. D.; CRUZ, J. P. Modelagem do crescimento e produção em classes de precipitação pluviométrica para Eucalyptus sp. Floresta, v. 45, n. 1, p. 117$128,2015$.

MORAES, M. A.; de MORAES, S. M. B.; DA SILVA, E. C. B.; KUBOTA, T. Y. K.; SILVA, A. M.; de RESENDE, M. D. V.; MORAES, M. L. T. Variação genética em progênies de Jacaranda cuspidifolia Mart. utilizando o delineamento sistemático tipo "leque". Scientia Forestalis, v. 41, n. 98, p. 175-183, 2013.

NASCIMENTO, D. F. D.; LELES, P. S. D. S.; OLIVEIRA NETO, S. N. D.; MOREIRA, R. T. S.; ALONSO, J. M. Crescimento inicial de seis espécies florestais em diferentes espaçamentos. Cerne, v. 18, n. 1, p. 159-165, 2012.

NAVROSKI, M.; ARAUJO, M. M.; REINIGER, L. R. S.; MUNIZ, M. F. B.; de OLIVEIRA PEREIRA, M. Influência do hidrogel no crescimento e no teor de nutrientes das mudas de Eucalyptus dunnii. Floresta, v. 45, n. 2, p. 315-328, 2015.

NELDER, J. A. New kinds of systematic designs for spacing experiments. Biometrics, v. 18, p. 283-307, 1962.

ODA-SOUZA, M.; BARBIN, D.; RIBEIRO J.R, P. J.; STAPE, J. L. Aplicação de métodos geoestatísticos para identificação de dependência espacial na análise de dados de um ensaio de espaçamento florestal em delineamento sistemático tipo leque. Revista Árvore, v. 32, n. 3, p. 499-509, 2008.

OLIVEIRA, A. C.; ROCHA, M. F. V.; PEREIRA, B. L. C.; CARNEIRO, A. C. O.; CARVALHO, A. M. M. L.; VITAL, B. R. Avaliação de diferentes níveis de desbaste nas propriedades da madeira e do carvão vegetal de Eucalyptus grandis $x$ Eucalyptus urophylla. Floresta, v.42, n.1, p.59-68, 2012

REINER, D. A.; SILVEIRA, E. R.; SZABO, M. S. O uso do eucalipto em diferentes espaçamentos como alternativa de renda e suprimento da pequena propriedade na região sudoeste do Paraná. Synergismus scyentifica, v. 6, n. 1, p. $10-18,2011$.

RESQUIN, F.; NAVARRO-CERRILLO, R. M.; CARRASCO-LETELIER, L.; CASNATI, C. R. Influence of contrasting stocking densities on the dynamics of above-ground biomass and wood density of Eucalyptus benthamii, Eucalyptus dunnii, and Eucalyptus grandis for bioenergy in Uruguay. Forest Ecology and Management, v. 438, p. 63-74, 2019. 
SANTOS, M. D.; JORGE, L. A. B.; MISCHAN, M. M.; SANTOS, A. L.; BALlARIN, A. W. Avaliação da Produção de Biomassa do Fuste de um Clone Híbrido de Eucalipto sob Diferentes Espaçamentos. Ciência Florestal, v. 27, n.1, p. 31-45, 2017.

SCHNEIDER, P. R.; FINGER, C. A. G.; HOPPE, J. M.; DRESHER, R.; SCHEEREN. L. W.; MAINARDI, G. Produção de Eucalyptus grandis Hill ex Maiden em diferentes intensidades de desbaste. Ciência Florestal, v. 8, n.1, p. 129-140, 1998.

SCHNEIDER, P. R.; FINGER, C. A. G.; SCHNEIDER, P. S. P.; FLEIG, F. D.; CUNHA, T. A. Influência do espaçamento no autodesbaste de povoamento monoclonal de Eucalyptus saligna Smith. Ciência Florestal, v. 25 , n. 1, p. 119-126, 2015.

SOUSA, G. C.; SILVA, J. V.; COSTA, C. C. Efeito dos tratos silviculturais na produtividade e na qualidade da madeira em plantações de Eucalyptus spp. Revista Agroambiente, v. 2, n. 2, p. 35-44, 2010.

STAPE, J. L.; BINKLEY, D., RYAN, M. G.; AZEVEDO M. R et al. The Brazil Eucalyptus potential productivity project: influence of water, nutrients and stand uniformity on wood production. Forest Ecology and Management, v. 259, p.1684-1694, 2010.

XAVIER, A.; SILVA, R. L. Evolução da silvicultura clonal de Eucalyptus no Brasil. Agronomía Costarricense, San José, v. 34, n. 1, p. 93-98, 2010 